\title{
Populism in Latin America: Old and new populisms in Argentina and Brazil
}

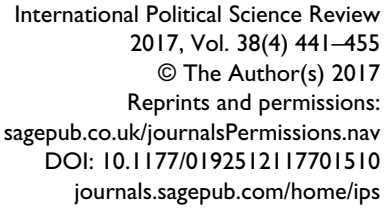

International Political Science Review 2017, Vol. 38(4) 44I-455

(C) The Author(s) 2017 Reprints and permissions: sagepub.co.uk/journalsPermissions.nav DOI: $10.1177 / 0192512117701510$ journals.sagepub.com/home/ips

@SAGE

\author{
Juan Grigera \\ University College London, UK
}

\begin{abstract}
There has been a renewed interest in populism in Latin America, sparked by the social mobilization against neoliberalism usually referred to as the 'Pink Tide'. Governments brought to power by the Pink Tide have been successful in reconstructing the conditions of capital accumulation as well as incorporating a new set of social movement demands. This article puts forward an interpretation of 'Pink Tide neopopulism' based on a political economy approach. It argues that the two factors of a crisis of neoliberalism in the region and the existence of social movements with unmet demands are not enough to explain the rise and demise of populism. The commodity boom needs to be added as an enabling condition for these transformations. By revisiting the debate in Latin America and proposing a different reading, the article redefines an overloaded term and provides a new analytical viewpoint from which to understand the 'historical task' of populism in Brazil and Argentina.
\end{abstract}

\section{Keywords}

Pink Tide neopopulism, political economy of populism, Lulism, Kirchnerism, South America

\section{Introduction}

In no other region of the world does populism and its discussion have such a long and rich political and socioeconomic history as in Latin America, even if the rural Russian and North American cases preceded it. In the past decade and a half, the coming to office of a series of centre-left governments (such as Lula in Brazil, the Kirchners in Argentina or Rafael Correa in Ecuador) has given new space (and meaning) to the term, both politically and academically.

This article proposes a reading of the latest wave of populism in Argentina and Brazil that stresses its enabling conditions and its historical differences with the classical populism of the post-Second World War period. It argues that the relationship between existing populisms in Latin

\section{Corresponding author:}

Juan Grigera, British Academy Postdoctoral Fellow, Institute of Americas, University College London, Gower Street, WCIE 6BT London, UK.

Email:j.grigera@ucl.ac.uk 
America and modes of capital accumulation is an important and understudied topic. Current debates have neglected this aspect in an (over)reaction to the deterministic approaches to populism in the literature of the 1960s and 1970s. The approach used here contributes to revitalizing the agenda on populism, which is currently dominated by a subfield of political science centred on discourse analysis.

This article is divided into two main sections. In the first section, the proposed approach is situated against other attempts to define populism in Latin America. The article then focuses on what I call 'Pink Tide neopopulism', which is understood as being distinct from classical post-war populism, and also from neoliberal populism. By situating the cases of Kirchnerism in Argentina and 'Lulism' in Brazil historically and identifying their specificities and structural traits, the perspective offers an original reading of them.

This article has been written during the coming to an end of the 'Pink Tide' (the group of governments that stem from processes of social mobilization against neoliberalism). Latin America 'was the only part of the world where rebellious social movements coexisted with heterodox governments' (Anderson, 2016: 22). Together with the end of the commodity boom this 'global exception' is closing. An attempt to contribute to understanding this process could not be timelier, for the question asked by Ianni, 'why do masses disappear from the political scenarios of each country?' (Ianni, 1973: 83),still resonates, despite the different context.

This study of the enabling conditions of populism, however, is also relevant to explaining the demise of populism and not just its rise. The study of the end of populist cycles has certainly been neglected, because of the assumption that populism is either a transitional anomaly before a 'return to normal' (e.g. modernization theory) or a quasi-universal category equivalent to 'true democracy' that has thus no specific demise. The approach presented in this article aims to overcome these shortcomings.

\section{Populism as an 'anomaly of modernization'}

In Latin American politics, 'populist' has been used as a term to describe almost any government, including some neoliberal ones of the 1990s. This has been reproduced in the academic context, sometimes making the analytical value of the concept worthless. Populism has often been understood as a predestined trait of Latin American regimes, doomed to be anomalous by nature. ${ }^{1}$ Such an essentialized understanding of populism should belong more to the domain of orientalism than that of political science.

There is, as well, a vast amount of research that responded to the above with a systematic development of the concept of populism into a category of greater analytical value. These could be broadly clustered in three waves that correspond to different eras of democratic rule in the continent. The first one took place in the 1950s and 1960s and was concerned with analysing the 1930s and post-war governments of Perón in Argentina, Vargas in Brazil and Cárdenas in Mexico, among others. A second wave that attempted to develop the concept of 'neopopulism' or 'neoliberal populism' took place in the 1990s and sparked a debate on whether some neoliberal governments, such as Menem's in Argentina, Fujimori's in Perú or Collor de Mello's in Brazil, could be framed under the old (but now rejuvenated) category. Finally, recent interest in populism revolved around the Pink Tide of governments arising from social mobilization against neoliberalism in the 2000s, such as those of Kirchner in Argentina, Lula in Brazil or Chavez in Venezuela.

The first wave of interpretations of populism in the 1950s and 1960s characterized it as an ideological-political phenomenon, revolving around different forms of manipulation of the 'available' and 'uneducated' masses by a small section of the elite or a paternalistic caudillo (leader). 
Personalism was opposed to institutionalism; in the political sphere populism signalled underdevelopment and backwardness.

In Argentina this trend was inaugurated by Gino Germani, for whom Peronism (and by extension other populisms in Latin America) was an anomalous product of modernization. ${ }^{2}$ The transition from traditional to modern societies was expected to follow a pattern of growth in mass participation according to the West-European ideal-type. This would occur through a slow consolidation of representative democracy: progressive reforms and participation in liberal or proletarian parties (Germani, 1971). For Germani, this transition in Latin America is upended by the emergence of 'degraded' forms of political activity due to the accelerated pace of changes during the crisis of 1930. This led to an early mobilization of masses that clashed with inadequate or backward political structures, hence giving rise to a 'deviation', that is, populism. This lack of political institutions or other means able to deal with (irrational and inexperienced) mobilized masses explains political crisis and the rise of a charismatic leader. These ideas were used by others such as Di Tella (1965) in a similar political context but also appropriated by the Left as an explanation for the 'lack' of proletarian class politics.

This trend in Brazil is similarly expressed by the first papers of the Grupo de Itatiaia in the 1950s (see Gomes, 1996), such as those by Hélio Jaguaribe (1968). Populism (mainly Varguismo, though also Adhemarismo and Janismo) is understood in the context of the problems of national development, as a specific political dimension of the transition from an agrarian export-oriented economy to a modern industrial one, where urbanization is the source of (new) masses. ${ }^{3}$ Francisco Weffort, in a similar vein, stressed the limits of the 'liberal oligarchic regime' of the early 20th century and how its crisis led to the construction of a new order, marked by 'populist manipulation' ${ }^{4}$ whereby the state at the same time controls and meets the demands of the new workers (Weffort, 1968).

This first group of readings reflected two ideas stemming from the pejorative and commonsense usage of populism, as highlighted in the introduction to this volume: the ideas of an exception to the ideal-type of Western European democracy and a charismatic leader. Nevertheless, this first attempt at understanding populism provided useful insights as well. It raised the question of the relationship between populism and structural socio-economic transformations. By identifying unexpected political outcomes of industrialization they opened up the question of the relationship and interdependence of these two phenomena. Second, the study of populism in this context understood it as a form of the state, whose other expressions (populist movements, for instance) are subsidiary to it, that is, the continuation of the populist state by other means. Third, as stressed by most commentators (Mackinnon and Petrone, 1998; Viguera, 1993), this early study of populism identified as the 'historical task' of populism the political incorporation of mobilized and politically excluded social groups, in the context of rapid changes and a crisis of traditional hegemony. These two elements, the institutionalization of conflict (underpinning the patronizing and biased idea of populist manipulation) and the background of a crisis of representation or governance will be returned to below.

This reference to the early theories of populism should also mention the tendency in the late 1960s and early 1970s to view populism in the context of dependency theory and Marxism. This began by defining populism as a socioeconomic project, that is, the reflection of a specific model of accumulation, namely import substitution industrialization (ISI). The thesis follows a functionalist logic: populism exists to fulfil the requirements of a specific mode of accumulation, ISI. As the success of ISI depends on state intervention and nationalization, and this requires a close control of social relations by the state and thus the political support of popular sectors, populism becomes the political form of this need. Redistributive policies, for instance, are functional both to 
guaranteeing the political support of the masses and to building a stronger internal market (Cardoso and Faletto, 1969; Vilas, 1988).

The crude determinism of this position has been widely criticized. Once populism is made the political requirement or consequence of ISI, then there could be no ISI without populism. Even a cursory overview of the historical record would be enough to prove this wrong. The ubiquity of ISI in the periphery (and beyond) in the post-war period was certainly not matched by an equivalent universality of 'populist regimes'. Instead, one could observe everything from other types of welfare state/ISI projects to anti-populist dictatorships to variants of conservative governments. If populism is nothing but the political expression of ISI, there is no specific issue to address as one could plainly refer to ISI: subsuming populism to ISI makes populism redundant as an analytical category. The conceptual failure of functionalism is more apparent when one looks more deeply into specific cases. For instance, the dictatorship that overthrew Perón in 1955 was unequivocally committed to putting an end to Peronism, though certainly not to ISI, and even took Raul Prebisch from ECLAC (UN's Economic Commission for Latin America and the Caribbean) as economic advisor. The ensuing democratic regime, the government of Arturo Frondizi (1958-1962), also under ECLAC's advice, was set up to expand 'developmentalist' projects while strictly repressing many of the rights extended by Peronism and attempting to guarantee that wages would be kept 'competitive'. Outside of Latin America examples of non-populist ISI abound. Confusing ISI with the modes of domination that were possible under it is plain reductionism.

The functionalist approach mirrors what was already present in the theories of populism as an anomaly of modernization. Their shortcomings are thus probably responsible for the complete absence of any reference to modes of accumulation or economic determinants of populism thereafter. If dependency theory attempted to explain populism as the functional requisite of ISI, modernization theory thought it was a distortion, a 'mass historical disorientation' due to the 'premature' incorporation of the masses into political life during late transitions to urban industrialization. Both theories expect a direct correlation between accumulation and social conflict, the former by assuming that actually existing populism reflects accumulation needs and the latter by expecting modernization to 'come with' Western representative democracy and seeing it as an anomaly when it does not. That having been said, taken as a whole the first populist experiences of Latin America emerged under common structural and historical configurations. It would therefore be problematic to avoid any reference to this common feature of the study of populism, especially when the question of accumulation and conflict still has to be theorized anew in non-linear and non-deterministic ways (Duarte and Fontes, 2013; Grigera, 2013).

In rejoining some elements of this debate we propose below to view ISI as the enabling condition of classical Latin American populism. First, following Zavaleta Mercado (1986; recently rejoined by Piva, 2013) there is an implicit assumption that the state has the capacity to redistribute. Zavaleta understands that the crisis of the masses needs to be matched with the institutional capacity of the state to respond, that is, to institutionalize, integrate and redistribute. Now, it is crucial not to naturalize the state capacity to capture and redistribute resources, a functionalist logic analogous to the approach above and yet commonplace in the contemporary literature. In the case of post-war populisms, these new resources are to be found in world market transformations and Latin American integration to it, that is to say, ISI.

The classical literature summarized to some extent the idea of the enabling condition by stating that 'the secret of populism is ISI' (Plá, 1991; Viguera, 1993) and understood that populism was not possible after its end (as rightly noted by Knight, 1998). Córdova suggested yet another connection between populism and ISI: that of the 'myth of industrialization'. Industrialization operated as the project that 'pacifies everything and solves everything' (Córdova, 1972: 66), as a common horizon of social transformation that would improve everyone's living condition; 'myth' 
in the sense of Barthes (1999), that is, as a second-order semiological system where a term is charged with a (politically relevant) connoted meaning. The 'myth of industrialization' does not refer to a farcical nature of industrialization but rather to the association of ISI with people's welfare, national development and a bright future. In sum, ISI enables not only the resources but also the construction of a cohesive myth of industrialization.

To summarize, the debate on postwar populism has tainted with determinism the question of the relationship between populism and modes of accumulation. In what follows, we propose to bring this issue back onto the agenda by rethinking both the role of state redistribution and the conditions of the emergence and demise of populism.

\section{Populism beyond the classical canon: The Pink Tide}

After a short-lived attempt at reframing the concept of populism as 'neopopulism' or 'neoliberal populism' on the thin grounds of a 'political style' (Knight, 1998: 226) and the profile of its voters in the 1990s, the academic literature on Latin America returned to populism in the beginning of the 21 st century with the so-called Pink Tide. This return is again accompanied by a common-sense usage of populism as demagoguery and authoritarianism, but also with a substantive theoretical renewal.

The return of populism to the contemporary agenda is dominated by comparisons with and revisiting of 'classical' (i.e. post-war) populism, thus inscribing Pink Tide neopopulisms within this specific genealogy. This is partly the reason why neopopulism, as in 'neoliberal populism', has become a historical curiosity, without any significant conceptual legacy. Neoliberal populism was framed as 'attempting a marriage of populism and neoliberalism' (Knight, 1998) and was used for cases such as Carlos Menem in Argentina and Alan Garcia or Alberto Fujimori in Peru. These governments were seen as populist because, even when implementing Washington Consensus reforms, their 'political style' included an appeal to the people, nationalism and promises of redistribution (eventually made pork barrel politics in the case of Fujimori). Even by the quite encompassing definition of Laclau (2005) however, these governments never systematically attempted an incorporation of democratic demands nor their articulation as a division between 'the people' (weak, oppressed, exploited) and its enemies. For instance, in the case of Menem, the term 'populist' was applied because of his 'charismatic character' and the tradition of the Peronist party to which he belonged (Palermo and Novaro, 1996:15). However, most analyses of his discourse identify a dominant use of liberal references, or stress its continuity with previous (non-populist) governments (Barros, 2005).

The main novelty in the past decade and a half has come from the works of Laclau, who proposes to understand populism as a formal political logic of constitution of identities. The 'logic of equivalence' divides society into two antagonistic fields, one of which is usually the 'people' that claims itself as the totality and is ultimately an empty signifier, while the 'other' exploits, oppresses, makes 'the people' suffer. Populism arises as the constitution of the former, as a subject that is able to absorb democratic demands. Populism for Laclau can be applied to varied phenomena from Maoism to Nazism, even some neoconservative governments (Laclau, 2005). This theoretical renewal has been key in saving the concept from 'condescension due to a waning error', though the review above shows that it was far from the first attempt to provide 'an alternative to liberal definitions' (Bray, 2015: 31).

At the same time, alongside the widespread use of Laclau's approach, there is growing discomfort with its limitations at a descriptive level: populism seems to be a political form, an antagonistic appeal from the people that underpins modern, representative democracy (Bray, 2015). This formalistic approach to populism makes the phenomenon conceptually almost universally possible, or 
at least each time there are unmet democratic demands (and, as Panizza (2005) notes, this implies that politically mobilized actors are being rejected by the political system). The existence of unmet demands thus 'opens the space for populism' (Panizza, 2016: 26) or is the 'condition for the emergence' of populism (Laclau, 2005: 78). In other words, the only enabling condition of populism is a crisis of representation, that is, the inability of the democratic system to represent 'the people'.

Thus there seems to be an identity between populism and politics or democracy, for it seems difficult to distinguish between them but for a certain fetishization of 'the people' (already present in the demos of democracy) and an ex-post identification of 'unmet demands'. Ultimately, both the enabling condition and the phenomenon end up being too generic, for unmet demands are a constant trait of almost every political system. Furthermore, this approach does not distinguish populist movements from populism in power or ruling populism, and thus obfuscates the issue of how and under what conditions the former can become the latter. Even more, without a careful examination it can lead to a functionalist logic (see above the point by Zavaleta: the existence of demands does not guarantee the state's capacity to redistribute).

Likewise, 'emergence' is a concept different from enabling condition. The crisis of representation is only able to explain the 'founding moment' of a populist regime, but it does not address why these regimes (or movements) come to an end. The implicit supposition is that, once present, populism will live for a while and not necessarily dissipate when the unmet demands are met or new ones arise. In other words, unmet demands are too generic to explain the emergence of populism and unable to explain its demise or its dynamics. Structuring the question around an 'empty signifier' (a redundancy, since signifiers are empty by definition) misses the manifold relations between social practices and discourse, emptying the understanding of the former or, in other words, emptying politics.

Are there any continuities to be found in such a long trajectory of the concept of populism? In a roundabout manner, there is a persistent focus on issues that, if addressed conceptually, can lead to a better understanding of Pink Tide neopopulism. Specifically, the litany of media stereotypes that 'populism, in essence, combines two lethal evils: disregard of the institutions of democracy and economic irresponsibility', 5 while misguided and non-rigorous, point towards two topics that have been present in most of the approaches to populism: institutions and economic redistribution. These, together with the conditions of emergence, will be the key elements in analysing neopopulism after 2000 .

First, populist regimes are key to (re)institutionalizing social conflict. Some theories understood populism as a factor of disintegration of institutionalized forms of political representation. Both modernization theories and Laclau underlined the crisis of traditional political institutions (either their inadequacy in a moment of transition or their increasing inability to absorb a chain of demands) in a way that has sometimes been understood as the emergence of forms of non-institutionalized political representation, for example, a populist leader who makes institutions obsolete. On the other hand, structuralist approaches understood populism as the 'political expression' of ISI and pointed out that capital accumulation requires a tighter state control of social relations, thus seeing populism as a form of institutionalization and a broadening of citizenship (e.g. labour rights during the governments of Perón or Vargas). Despite this apparent disagreement, each of these theories emphasizes different moments and captures different aspects of populism. While the former looks at the conditions of the emergence of populism where institutions are actively challenged, the latter insists on its structural traits, that is to say, the long-term effect of the regime. By looking at the dynamics of populism a more nuanced picture can be constructed: the creation of new representations is not to be confused with the disappearance of institutions. The claim of the leader that 'the people' can come directly to him/her is the expression and signalling of the ongoing institutional transformations and the attempt at being identified with the new institutional channels. 
In sum, after a first stage of institutional disruption the direction of populism is towards institutionalizing social conflict, to the extent that one could probably understand that the historical task of populism is institutionalizing social conflict (a perspective not far from Laclau's idea of incorporation of demands as populism's implicit objective).

Second, we should consider the question of the availability of resources for the state to capture and redistribute. While most definitions of populism-as-evil highlight 'economic irresponsibility' (a very broad condemnation of any state expenditure beyond the neoliberal canon, for example Dornbusch and Edwards (2007)), ${ }^{6}$ it is true that some sort of redistribution has been key to almost all Latin American populisms. ${ }^{7}$ Redistribution is present as a feature of populism in most analyses (apart from those stemming from Laclau) although it is frequently noted as a by-product of some sort of clientelist politics (i.e. to build political support). In structuralist analyses, redistributive policies are also interpreted as being functional to ISI's need of a stronger internal market.

However, we should note two less well-represented elements: first, redistribution as a consequence of the relative power of a social group, that is to say, the satisfaction of a demand in its own right and not as a functional product of clientelism nor national development. Second, as already noted by Zavaleta above, redistribution presupposes the existence of (new) resources to be appropriated by the state. In sum, the widely mentioned issue of redistribution under populism should be framed under the enabling condition of available resources, not as pork barrel politics but rather as a reinstatement of the state as a mediator capable of arbitration of social conflict. In other words, in the populist redistribution, what is at stake is state power as a mediator; its capacity to institutionalize redistributive conflicts. ${ }^{8}$

Finally, a crisis of representation as a condition of emergence of populism is another common theme in the literature (Mackinnon and Petrone, 1998). From Germani's (1971) idea that there were groups with an 'excess' of demands, to Laclau's (2005) chain of equivalence, there is hardly any aspect more widely discussed. The specific nature of this crisis, the social groups in question and their mobilization capacity will give shape to the populist regime.

In what follows, we will assess Pink Tide neopopulism in Argentina and Brazil by paying attention to their enabling condition, that is to say, to the crisis of representation and the availability of redistributable resources that allow for the (re)institutionalization of social conflict and the reinstatement of state power as a mediator.

\section{Argentina's Kirchnerism: $200 \mathrm{I}$ and the commodity boom}

The outbreak of the largest crisis in recent Argentine history, in 2001-2002, marked the turning point for a country that used to be the 'poster boy' of Washington consensus policies. It opened a long period of turmoil (including defaulting on foreign debt and the expropriation of bank savings in foreign currencies) and a crisis of governance signalled by the symptomatic call 'Que se vayan todos' (Out with them all!) and the succession of five presidents in a month. The political and economic bankruptcy of neoliberal policies meant the opening of a new fluid equilibrium that lasted until 2015. This was inaugurated by two politicians from the Peronist tradition (Adolfo Rodriguez Saá and Eduardo Duhalde) followed by Nestor Kirchner (elected in 2003) and Cristina Fernández de Kirchner (elected in 2007 and 2011). The period after the crisis has been repeatedly studied under Laclau's paradigm, seeing the Kirchners as a phenomenon that posed a new re-articulation of hegemony built on an antagonism of the people to foreign capital, the concentrated groups or the 'anti-patria' (anti-patriotic) newspaper Clarin (among others Aboy Carlés, 2003; Panizza, 2016).

As previously argued, this formal/discursive dimension of populism does not account for the differences between post-war populism and Pink Tide neopopulism. Classical populism (the first Peronism) constituted a response to the crisis of the "infamous decade ${ }^{\prime 9}$ and the growth of working 
class demands in the new economic context of the post-war period. Thus, Peronism gave citizenship to the working class, that is, carried out a state restructuring that would install institutional mediation of labour/capital conflict. This institutionalizing of the working class movement through the legalization of trade unionism (alongside a demarcation of 'legitimate' and 'illegitimate' union practices and tendencies) was also accompanied by a redistribution of income in the form of wage social security, that is, the specific form of citizenship was tied to job rights.

Pink Tide neopopulism differs in several key respects from this model. First is the specific context of a structural crisis. Neopopulism is the response to the political crisis created by the opposition to neoliberalism by different social movements, whose cycle of struggle began in 1996: unemployed workers (piqueteros), public sector unions, human right movements and, after 2001, asambleas (assemblies) and recuperated factories (Grigera, 2006). The incorporation of demands follows manifold paths, as Piva (2013) rightly summarizes: the state responds to unemployed workers' demand for jobs and workfare (while 'tough piqueteros' are delegitimized, see Svampa and Pereyra (2004)); demands for justice on human rights violations from the last dictatorship are recognized and judicialized; trade unions are 'revitalised', that is, recover some power of mediation of capital/labour relationships in a context of enormous growth of employment (mostly informal); and there are a record number of collective bargain agreements (Atzeni and Ghigliani, 2008).

The 'myth of industrialization' is used by Kirchnerism in a farcical way, appealing to the memory of the glorious past of post-war ISI, together with a discourse of 'reindustrialization' whose only empirical ground is economic recovery. The form of the state is reconfigured, downgrading the ministry of finance that used to be effectively autonomous and on top of all other powers after neoliberal reforms (Bonnet and Piva, 2013). Different social movements are incorporated as civil servants and functionaries as a way of institutionalizing demands, but also shaping differential access to the state by mobilized social groups (thus effectively 'dividing and conquering)'. In sum, the recomposition of governance was articulated through direct redistribution, indirect redistribution thanks to changes in the mode of accumulation, and through the institutionalization of demands.

As outlined above, the intertwined processes of institutionalization and redistribution are articulated by the state capacity to use and capture resources. Unlike classical populism, ISI is certainly not the structural condition allowing the existence of state appropriable surplus. Pink Tide neopopulism is founded rather on a more modest set of changes: a large devaluation in 2002/2003 that allowed for the modest substitution of some imports, the foreign debt default that freed an important share of the national budget from interest repayments (Piva, 2013) and, most importantly, the commodity boom cycle. This last element has been repeatedly outlined as being central to the understanding of the Pink Tide's (limited) redistribution, and sometimes in a deterministic fashion of the Pink Tide tout court (Weyland 2009). These changes in capital accumulation made the populist response to the crisis possible, thus enabling the articulation of a process of institutionalization of social conflict.

Commodity prices skyrocketed during 2002-2011 in a region heavily dependent on exports of primary commodities. In Argentina they accounted for $70 \%$ of the exports during this period (United Nations Commodity Trade Statistics Database - COMTRADE) where the country's terms of trade improved $68 \%$ and its total exports of primary products grew $300 \%$ in current prices (ECLAC's Statistics Database - CEPALSTAT). One indicator of the political importance of commodity exports during the post-2001 crisis period is seen in the conflicts around export tariffs (retenciones a las exportaciones). In 2008, after the government's attempt at reforming the export tariff to allow for automatically adjustable rates (pegged to each commodity's international price) the country went into the largest agricultural lock out in decades. The end of exceptional international conditions for Argentinian primary commodities after 2012 has re-opened the distributive 
question, first marked by the end of the primary fiscal surplus. If Pink Tide neopopulism is to be understood beyond the discursive apparatus, a closer look at the political economy of these resources is necessary, especially in light of the temporal coincidence with the closure of the neopopulist cycle.

There are also a number of elements that are specific to Pink Tide neopopulism that distinguishes it from post-war populism. First, there is a change in the mobilized subject and in the nature of 'citizenship'. If it was the working class under Peronism, a different set of social movements and the urban poor are the elements given space under Kirchnerism (Wylde, 2012). Then, the nature of the process of incorporation of social groups in institutionalized democracy is conditioned by a history that is reproduced and re-signified. In other words, that 'primitive incorporation' (Peronism) is politically used by Kirchnerism (Piva, 2013). And finally, the nature of the institutionalization of this neopopulism is strikingly different to the universal citizenship of the welfare state. Kirchnerism has produced a fragmented citizenship in two regards. First, there is a deepening of the dualization of the labour market. Despite an enormous growth of employment during these years, 'informal' (non-registered) jobs dominated, alongside a growth in wage disparity, thus widening the gaps in a social welfare system traditionally structured as a set of rights associated with a formal job. Second, in the terrain of a social safety net, neopopulism has chosen to structure social expenditure around Conditional Cash Transfers (CCTs) that are by definition a targeted and financialized approach to welfare (Lavinas, 2013).

To summarize, Kirchnerism showcases the key elements common to populism outlined in our first sections. Stemming as a response to a crisis of representation, it sets out to institutionalize those conflicts, through indirect and direct redistribution, enabled by the unique economic recovery made possible by devaluation and a commodity boom. The latter was key to allow for state appropriation of resources through export tariffs, a sensitive political issue throughout the period. The demise of the enabling condition meant the end of this populist cycle for Argentina.

\section{Lula's Brazil: 'I am not a populist'}

In Brazil 'the era of populism' began with the economic crisis of 1930s (together with the end of República Velha through a military coup ${ }^{10}$ and ended in 1964 . This widespread agreement on a period delimited by coups d'état speaks as well of the assumption that populism is pervasive and possible without democratic rule (i.e. considering the possibility of a populist dictatorship). The military coup of 1930 embodies the paradox of a dictatorship attempting to democratize the state and the entry of popular masses into politics (somewhat similar to the coup of 1943 in Argentina that lead to Peronism).

The main characteristics of populism outlined above are also valid for the Vargas era. The rapid transformation of the form of the state implies an institutional widening of its social base. A first dimension is that of democratization from above. Besides outlining the basis for ISI, Vargas introduced the largest change in capital/labour relations of the century. This was mainly in the form of expanding rights for urban labour (i.e. manufacturing and services), thus large landowner interests were not immediately affected. As in Argentina the incorporation of the masses into Brazilian democracy - giving them 'citizenship' - was done through labour rights. In other words, the state appears to citizens, and is constituted, as a mediator of social relationships at the level of capitallabour relations.

Now, as much as Vargas' populism has been traditionally included within the cases of post-war populism in Latin America, whether Lula should be understood in the context of Pink Tide neopopulism is a contentious issue. Lula came to office in 2002, the fourth election since the end of the military dictatorship in 1985. Since the campaign, Lula's discourse avoided the construction of an 
antagonism between the people and others, and in his Carta ao Povo Brasileiro (Letter to the Brazilian People, June 2002), ${ }^{11}$ Lula's electoral 'love letter' to the business community, he made a commitment to market economy, macroeconomic stability, the control of inflation and fiscal equilibrium, while still mentioning the need to reduce poverty and inequality. The letter not only signalled continuity with the neoliberal order, but also codified one of Lula's many gestures of differentiation from Varguism.

Despite Lula's explicit disavowal of populism, the term has been thrown at his government and him repeatedly, usually with weak arguments. For instance, it has been grounded in support from the poor, after a shift of the electoral base to poorer sections of the voters in the 2006 election. Bethell is right to point out that 'his success with the poorer sections of society was not, however, the result of a typically polarizing anti-elite, anti-globalization, anti-American populist discourse', so that 'it remained difficult therefore to describe Lula as a neo-populist of the Left' (Bethell, 2013: 198). Or it has been argued that Lula is a populist on the basis of his charismatic appeal or his clientelistic networks, or his appeals to 'the people'.

Still, in order to usefully characterize the ruling Partido dos Trabalhadores (PT), proving the existence of appeals to 'the people' and polarization is not enough, nor do these give a sense of how it relates to previous populisms in Brazil and to other contemporary neopopulisms in Latin America. In Brazil, the strongest attempt at characterizing the PT or Lulism was not done following Laclau but rather a liberal understanding of populism. For instance, Cardoso and his followers characterized Lula as a populist on the grounds that he is a charismatic leader who 'purchases the favour of the masses with charity and flattery' and for being a 'budgetary populist' thus Lula embodies the 'most regressive traditions of the continent' (Anderson, 2011: 7). However, despite its impact on the media, this reading is marginal in academic studies.

The main lines of academic analysis of Lula's government begin in 2003 with Chico de Oliveira (2003) and extend to André Singer (2012). They include a number of varied explanations ranging from classical sociology, Gramscianism and Bonapartism, to theories of electoral realignment. Even though they do not agree in framing Lulism as neopopulism, they do mention a number of elements that are common to what we have identified as its characterization.

First of all, there is an overwhelming consensus that the PT in power was a strong force of demobilization, through the institutionalization of some demands and also through the incorporation of social movement personnel into the state. Oliveira states that this demobilization is a product of the alignment of the financial interests of PT and trade union officials, through their increasing dependence on public funds and financialized pension funds. For him this was part of a process of 'kidnapping' of social movements (Oliveira, 2003) - mainly the Movimento dos Trabalhadores Sem Terra (MST) ${ }^{12}$ by the state. Sallum Jr and Kugelmas (2004: 256) see a 'liberal-developmentalist' turn that implies strong state intervention. Werneck Vianna (2007) understands Lula as someone who de-politicized social conflict. Singer (2012) sees in the realignment of the electoral base of Lula towards the 'sub-proletariat' the main drive towards peaceful resolution of social conflict, as a demand of this class that is both hoping for the state to decrease inequality and afraid of disorder and conflict created from social movements. In sum, behind different causal explanations of why institutionalization takes place we find strong agreement that 'the signature of his rule was, if anything, demobilisation' (Anderson, 2011: 7), or in Singer's words the 'pasteurization' of social mobilization (Singer, 2012: 21).

A second element in most analyses of Lulism is that of redistribution or the limited nature of it, somewhat reflected in Lula's statement that 'it's cheap and easy to look after the poor'. ${ }^{13}$ The triad of Bolsa Familia (a large CCT program), crédito consignado (consumer credit), and university 
quotas and increases to the minimum wage have become trademarks of PT rule, a sort of motto, repeated on many occasions. As Anderson has noted ' $[\mathrm{n}] \mathrm{o}$ less important has been the symbolic message it delivers: that the state cares for the lot of every Brazilian, no matter how wretched or downtrodden, as citizens with social rights in their country' (Anderson, 2011: 5). However, following our analysis above for CCTs under Kirchnerism, these rights are closer to a 'fragmented citizenship' than to the model of post-war populism. The impact of the commodity boom on Brazil is also important: the share of primary products in exports went from $40 \%$ to $55 \%$ between 2000 and 2012 and they grew in value terms seven times (CEPALSTAT). Even when redistribution is limited in its amount (and as repeatedly noted it was not done at the cost of the rich), it is one of the political axes of PT's rule.

The limited nature of its redistributive policies, the effectiveness at demobilizing and the timid use of antagonistic discourse when compared to other governments of the Pink Tide (such as Venezuela's, but also Kirchnerism as analysed above) makes Lulism seem like a 'less intense' form of neopopulism. With a similar integration into the world market as other countries of the region, Lulism was able to profit from the commodity boom by raising taxes from it. However, the specificity of Brazil lay in the fact that the resistance to neoliberalism was not as strong as elsewhere in the region. In other words, the mobilization of 'unrepresented masses' and crisis of representation that provide the founding moment of populism, though present, are less radical. Without a crisis of the dimension and depth as that of 2001 in Argentina, Lulism could navigate a moderate pace of reform for its variant of neopopulism.

The end of PT's cycle is also peculiar. On one side the enabling condition of the commodity boom is closing. However, the massive demonstrations of June 2013 that were sparked by the issue of transport and those of 2015 from anti-PT organizations would also need to be accounted for. The recent impeachment of Dilma in 2016 and the blow to PT in the municipal elections, together with the ongoing political crisis, seem to indicate that the party is no longer able to represent or effectively channel the social sectors it used to.

In sum, even though Lulism and the PT government have not been unanimously identified as populist, we have found that they too can be consistently thought as a case of Pink Tide neopopulism. Unlike Kirchnerism, the PT stems from a remarkable cycle of trade union and social movements' resistance to neoliberalism. Trade unions and the MST were precisely the mobilized sectors demanding representation (and redistribution), even when this was not as explosive as in Argentina. The historical task of the PT was to institutionalize, integrate and demobilize these sectors and demands, in a context of economic growth that allowed the state to capture and redistribute new resources. The 'low intensity' of this populism, including the form of the appeals to an antagonistic discourse (Ab'Saber, 2011) is mainly conditioned by the 'low intensity' of the crisis. The end of the cycle is, however, also following the closure of the exceptional cycle of its enabling condition, the commodity boom.

\section{Conclusions}

We have briefly revisited populism in Latin America and its interpretations with an attempt at rescuing recurring elements that would allow for an interpretation of Pink Tide governments beyond the canon of discursive analysis. This article has stressed that the widely recognized processes of institutionalization behind populist regimes have an implicit enabling condition: the ability of the state to capture and redistribute (new) resources.

Even this modest introduction of political economy has proven to be helpful for a better understanding, not only of populism's emergence, but also of its demise. While our proposal is consistent 
with the longstanding agreement that populist regimes stem from crises of representation, it provides new hints on when a populist response to such a crisis is at all possible.

We have thus explained the emergence of Kirchnerism and Lulism as responses to the crisis of neoliberalism. We have opted to use the term 'Pink Tide neopopulism' to distinguish them from classical post-war populism, and 'neopopulism' from neoliberal populism. The differences between both were traced in the nature of the mobilized subject, the enabling condition, and the depth and type of the crisis.

In rejoining the question of the structural conditions of populism it is important not to return to the history of determinism and functionalism that tainted the historical debate (and that led to the reluctance to even reference this issue). An enabling condition is not a 'fundamental cause' of neopopulism (as in Weyland, 2009) but rather the means that allow for the resolution of a crisis. The causes of populism stem from the crisis of neoliberalism (that preceded the boom), the existence of various 'unmet demands' and the availability of rents.

Pointing to the importance of crisis also serves as a key analytical issue. First, a common 'fluidity' and the changing nature of the populist state are traits consistent with the weakness of a state that stems from a crisis. This sets right the contradiction in the widespread idea that populist states are 'strong' and that they are the product of a crisis. In rejoining Harvey's (2005) definition of the neoliberal state as a strong state, not because of its regulatory power or interventionism but rather because of its capacity to guarantee the reproduction of social relations and its command over the working class, one can regard the populist state as weak or 'in a constant fluid state, given that [it] must constantly negotiate to overcome the gaps between... rhetoric and socioeconomic reality' (Leiva, 2008: 241). Second, the depth of the crisis accounts for the differences in their degrees of radicalism, a point that we used to explain some of the differences between Kirchnerism and Lulism.

Another element of analysis has been the 'historical task' of populism, and we have identified a consensus around the institutionalization of social conflict and the reinstatement of the state as its mediator. The key actors of resistance to neoliberalism in each national case had a subset of their demands incorporated and they accepted a redefinition of resistance's 'legitimate' practices (e.g. the repression of tough piqueteros or the domestication of MST's land grabbing through the legalization and regulation of credit and state support).

By understanding the enabling conditions of populism we have also set out to explain the conditions of the demise of populism. As much as classical populism has been made impossible after the changes in the world market that made ISI a historical curiosity, the fate of Pink Tide neopopulism seem also to be tied to that of the commodity boom.

\section{Acknowledgements}

I would like to thank Vedi Hadiz, Angelos Chryssogelos, Samuele Mazzolini, the anonymous reviewers and participants in the seminars 'World Populism' at Chatham House and UCL for their comments, suggestions and feedback.

\section{Funding}

This work was supported by British Academy Postdoctoral Fellowship.

\section{Notes}

1. As noted by Ferreira (2001), this was not the case before the Second World War.

2. For a broader overview of populism and the importance of modernization theories in its theorization, see the introduction to this volume. 
3. Note that this was intended as a complementary political thesis to the main modernization theory stemming from cepalismo. In this sense populism was, as much as underdevelopment, a key postcolonial experience.

4. Weffort reconsidered the idea of manipulation in his later writings and renamed it 'populist alliance'.

5. A post-impeachment issue of Exame (São Paulo) Lamounier, Bolívar 'Não precisamos de salvadores', 25 May 2016, 10-12. For similar statements see, for example, F.H. Cardoso, lecture at OAS (Organization of American States), 30 March 2006, Luis Alberto Romero (Andes, 12 December 2014 and Clarin 9 April 2014), José Nun (La Nación, 19 December 2012).

6. In other words, any state expenditure that challenges the orthodoxy of fiscal equilibrium targets. This definition of populism would overlap with that of Keynesianism or ECLAC structuralism.

7. There is also potentially a relationship between redistribution and some definitions of the 'charismatic leader', though its analysis is beyond the scope of this article.

8. This is another aspect of the 'institutionalization drive' already mentioned above. This 'economic incorporation' of social groups, complementary to the 'political' one, is at the antipodes of neoliberal approaches. While populism attempts a mode of mediation the neoliberal state leaves this to market mechanisms.

9. This period was inaugurated by the coup d'etat of 1930 and was characterized by electoral fraud, corruption and persecution of the working class and the political opposition, as well as by the interwar economic turmoil and the Great Depression.

10. The Republica Velha (Old Republic) is the period from 1889 until the military coup of 1930. Democracy was nominal, with rigged elections, corruption among elites and the alternation of presidents between large landowners from São Paulo and Mina Gerais.

11. The implicit reference is to the epitome of populist discourse, Vargas' 'testament', another letter to the Brazilian people.

12. Movimento dos Trabalhadores Sem Terra (Landless Workers' Movement), one of the largest social movements in Latin America articulating resistance to neoliberalism.

13. Speech to new ministers on 31 March 2010.

\section{References}

Aboy Carlés, Gerardo (2003) Repensando el Populismo. Política y Gestión 4: 9-34

Ab’Saber, Tales (2011) Lulismo, Carisma Pop e Cultura Anticrítica. São Paulo: Hedra.

Anderson, Perry (2011) Lula's Brazil. London Review of Books 33(7): 3-12.

Anderson, Perry (2016) Crisis in Brazil. London Review of Books 38(8): 15-22.

Atzeni, Mauritzio and Pablo Ghigliani (2008) Nature and Limits of Trade Unions' Mobilisations in Contemporary Argentina. Amsterdam: Labour Again. Available at: http://www.iisg.nl/labouragain/ documents/atzeni-ghigliani.pdf

Barros, Sebastián (2005) The Discursive Continuities of the Menemist Rupture. In: Francisco Panizza (ed) Populism and the Mirror of Democracy. London: Verso.

Barthes, Roland (1999) Mitologías. Madrid: Siglo XXI.

Bethell, Leslie (2013) Populism, Neo-Populism and the Left in Brazil. In: Carlos de la Torre and Cynthia Arnson (eds) Latin American Populism in the 21st Century. Baltimore, MD: John Hopkins Univeristy Press, pp. 179-202.

Bonnet, Alberto and Adrián Piva (2013) Un Análisis de los Cambios en la Forma de Estado en la Posconvertibilidad. In: Juan Grigera (ed) Argentina Después de la Convertibilidad (2002-2011). Buenos Aires: Imago Mundi, pp. 33-62.

Bray, Michael (2015) Rearticulating Contemporary Populism. Historical Materialism 23(3): 27-64.

Cardoso, Fernando Henrique and Enzo Faletto (1969) Dependencia y Desarrollo en América Latina. Mexico: Siglo XXI.

Córdova, Arnaldo (1972) La Formación del Poder Político en México. México DF: Era.

Di Tella, Torcuato S. (1965) Populismo y Reforma en América Latina. Desarrollo Económico 4(16): 391-425. 
Dornbusch, Rudiger and Sebastian Edwards (2007) The Macroeconomics of Populism in Latin America. Chicago, IL: University of Chicago Press.

Duarte, Adriano and Paulo Fontes (2013) Asociativismo Barrial y Cultura Política en la Ciudad de San Pablo, 1947-1953. Nuevo Mundo-Mundos Nuevos 13: 64-84.

Ferreira, Jorge Luiz (2001) O Nome e a Coisa: O populismo na política brasileira. In: Jorge Luiz Ferreira (ed) O Populismo e sua História: Debate e Crítica. Rio de Janeiro: Civilização Brasileira, pp. 60-124.

Germani, Gino (1971) Política y Sociedad en Una Época de Transición. Buenos Aires: Paidós.

Gomes, Angela de Castro (1996) O Populismo e as Ciências Sociais no Brasil: Notas sobre a trajetória de um conceito. Tempo 1(2): 31-58.

Grigera, Juan (2006) Argentina: On crisis and a measure for class struggle. Historical Materialism 14(1): 221-248.

Grigera, Juan (2013) Esperando a E.P. Thompson. Desindustrialización y formación de clases sociales en Argentina (1976-2001). Mundos do Trabalho 5(10): 71-88.

Harvey, David (2005) The New Imperialism. Oxford: Oxford University Press.

Ianni, Octavio (1973) Populismo y Relaciones de Clase. In: Octavio Ianni (ed) Populismo y Contradicciones de Clase en América Latina. México: Era, pp. 83-150.

Jaguaribe, Helio (1968) Brasil: ¿Estabilidad Social por el Colonial-Fascismo? In: Celso Furtado (ed) Brasil Hoy. Mexico: Siglo XXI, 28-53.

Knight, Alan (1998) Populism and Neo-Populism in Latin America, Especially Mexico. Journal of Latin American Studies 30(2): 223-248.

Laclau, Ernesto (2005) On Populist Reason. London: Verso.

Lavinas, Lena (2013) 21st Century Welfare. New Left Review II 84: 5-40.

Leiva, Fernando (2008) Latin American Neostructuralism: The contradictions of post-neoliberal development. Minneapolis, MN: University of Minnesota Press.

Mackinnon, Maria M and Mario A Petrone (1998) Los Complejos de la Cenicienta. In: Maria M Mackinnon and Mario A Petrone (eds) Populismo y Neopopulismo en América Latina: El problema de la Cenicienta. Buenos Aires: Eudeba.

Oliveira, Francisco de (2003) Crítica à Razão Dualista - O Ornitorrinco. São Paulo: Boitempo Editorial, pp. 121-150.

Palermo, Vicente and Marcos Novaro (1996) Politica y Poder en el Gobierno de Menem. Buenos Aires: Norma.

Panizza, Francisco (2005) Introduction. In: Francisco Panizza (ed) Populism and the Mirror of Democracy. London: Verso.

Panizza, Francisco (2016) Populism, Social Democracy and the Tale of the Two Lefts in Latin America. In: Anthony Petros Spanakos and Francisco Panizza (eds) Conceptualising Comparative Politics. London: Routledge, pp. 192-214.

Piva, Adrián (2013) ¿Cuánto Hay de Nuevo y Cuánto de Populismo en el Neopopulismo? Trabajo y Sociedad 21: $135-157$.

Plá, Alberto J (1991) Notas Sobre el Agotamiento del Populismo. Cuadernos del Sur 12: 41-48.

Sallum Jr Brasílio and Eduardo Kugelmas (2004) Sobre o Modo Lula de Governar. In: Sallum Jr Brasilio (ed.) Brasil e Argentina Hoje: Politica e economia. Bauru: EDUSC.

Singer, André (2012) Os Sentidos do Lulismo. São Paulo: Companhia das Letras.

Svampa, Maristella and Sebastián Pereyra (2004) Entre la Ruta y el Barrio. Buenos Aires: Biblos.

Vianna, Luiz W (2007) O estado novo do PT. Blog. Gramsci e o Brasil. Available at: http://www.acessa.com/ gramsci/?page= $=$ isualizar\&id $=755$

Viguera, Aníbal (1993) ‘Populismo’ y ‘Neopopulismo’ en América Latina. Revista Mexicana de Sociología 55(3): 49-66.

Vilas, Carlos M (1988) El Populismo Latinoamericano: Un enfoque estructural. Desarrollo Económico 28(111): 323-352.

Weffort, Francisco (1968) El Populismo en la Política Brasilera. In: Celso Furtado (ed) Brasil Hoy. Mexico: Siglo XXI, 54-84. 
Weyland, Kurt (2009) The Rise of Latin America's Two Lefts: Insights from Rentier state theory. Comparative Politics 41(2): 145-164.

Wylde, Christopher (2012) Latin America after Neoliberalism. New York, NY: Palgrave.

Zavaleta Mercado, René (1986) Lo Nacional-Popular en Bolivia. Mexico: Siglo XXI.

\section{Author biography}

Juan Grigera is a British Academy Postdoctoral Fellow at UCL Institute of the Americas. He completed a PhD from the University of Buenos Aires after being awarded an MSc in Development Studies from the London School of Economics. His work on the Argentine 2001 crisis, ECLAC, deindustrialization and class formation has been published in various journals. His latest research project is entitled Bringing the global market back in. Industrialising and exporting commodities: Argentina and Brazil (1950-2010). He is an editor of the Historical Materialism book series and journal. 